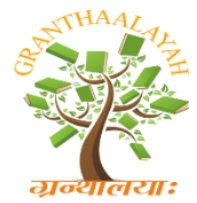

\author{
INTERNATIONAL JOURNAL OF RESEARCH - \\ GRANTHAALAYAH \\ A knowledge Repository
}

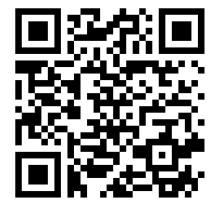

Science

\title{
SUSTAINABILITY OF URBAN LAND IN IRAQI CITIES THROUGH MULTI STORIES RESIDENTIAL BUILDINGS: DOUR CITY - CASE STUDY
}

\author{
Mudher Abbas Ahmed ${ }^{1}$, Nabil T. Ismael ${ }^{* 2}$ \\ ${ }^{* 1}$ Al_Dour Technical Institute, Northern Technical University, Iraq \\ ${ }^{2}$ Architectural Engineering, College of Engineering, University of Diyala, Iraq
}

\begin{abstract}
The horizontal expansion of cities is a problem in itself because this leads to waste in the urban land and override on agricultural land in many cases, so the percentage of residential use could be large if compared to other uses of other urban land in cities. As a result, many countries have adopted the style of vertical buildings ( 3 - 5) floors for low height housing reaching to higher elevations, commensurate with the value and location of the urban land within the city because these residential buildings are characterized by suitable residential densities, efficient and economical use of the urban land, as well as the integrity of services that achieve the conditions for suitable and comfortable standards for housing. The problem of this research is coming from the reliance on horizontal residential building in providing the housing units in time of essential need for housing accompanied by waste in urban land with high proportion of residential use. The research is aimed to reduce the proportion of residential use of urban land in cities, including Iraqi cities, and make them close to the percentage of residential use in the world through the relying on the vertical residential building type as developed and integrated residential complexes from planning, design and service aspects. This research supported by field study of one of the multifamily housing complexes. This residential complex consisting of residential units in the form of apartments, which represent the vertical residential building.
\end{abstract}

Keywords: Land Use; Residential Environment; Scarcity; Urban Land; Vertical Residential Construction.

Cite This Article: Mudher Abbas Ahmed, and Nabil T. Ismael. (2019). "SUSTAINABILITY OF URBAN LAND IN IRAQI CITIES THROUGH MULTI STORIES RESIDENTIAL BUILDINGS: DOUR CITY - CASE STUDY." International Journal of Research Granthaalayah, 7(5), 90-105. https://doi.org/10.29121/granthaalayah.v7.i5.2019.828.

\section{Introduction}

The adoption of vertical building housing complexes method has the effect of limiting the increase in the horizontal expansion of cities, which results in many negatives if not according to proper planning studies. This system of vertical housing is a developed economic and social system 
adopted by many countries as they found the suitable solution for the housing problems due to the speed of implementation compared to the construction of the horizontal single housing, as well as the large number of housing units that can be built or produced by following this system, which can be typical also through the ready-made construction or through concrete or steel structural construction or the mix between them. Therefore, there must be a clear policy and proper preparation of the requirements for adoption of this method of construction. On the social level, there are many people prefer to live in, especially families consisting of a few individuals or newly married. This type of construction is successful and attractive if applied in accordance with the appropriate planning and design standards that make the residential complex with integrated services and recreational, cultural and social activities, that is functionally integrated.

The problem of this research is coming from the continuity to follow the method of horizontal residential construction in providing housing units at the time of urgent need for housing, accompanied by the growing waste in urban land, and the high proportion of residential use.

The research hypothesis assumes that the approach to constructing functionally integrated vertical housing complexes while minimizing the construction of single residential housing could contribute to reducing the percentage of residential use in urban land use which suffer from scarcity as well as population increase.

The research is aimed to reduce the proportion of residential use of urban land in cities, including Iraqi cities, and make them close to the proportions of residential use in the world through the relying on the pattern of vertical residential construction in the form of advanced residential complexes with integrated planning, design and services.

The research is depending on quantitative descriptive and analytical approach, through which it is possible to achieve the treatment of the research problem and prove the validity or false of the hypothesis as well as scientific references in this field.

\section{The Importance and Scarcity of Urban Land in The Urban Environment of The City}

The land has an essential and decisive importance in the possibility of securing housing for the population. The urban land is characterized by its versatility. Residential use is one of these uses that competes with other land uses such as industrial, commercial, administrative, entertainment, cultural, etc. The urban land for housing, which provides the basic facilities within the acceptable limit, the foothold of the low-income family in urban society and the guarantee for them, because it achieves safety and stability as well as give them a sense of prestige and dignity (Ahmed, 2004, pp. 6-7). The provision of land for residential use is an important factor that has a direct impact on the size of effective demand in the housing market. In addition, the high rate of income or increase in the volume of loans granted may not necessarily increase the volume of effective demand for housing units without the availability of residential land. In some cases, the cost of residential land is about $50 \%$ of the total cost of residential unit in the new residential areas and neighborhoods and even more in the central areas of cities (Al-Haidari, 1981, p. 52). The increase in the cost of the land is reflected directly on the cost of the housing unit, so it is higher than the possibility of low income in many cases, which leads them to search for other residential areas away from the city center, and this in turn leads to increase the cost of transport and the high cost of land reflected 
on the population density of the city, leading to high densities in the central areas significantly (AlHayti, 1976, p. 255). Therefore, the issue of residential land should be managed and directed in such a way to ensure a system capable of enhancing its optimal use. Central and local authorities should have an effective role in providing land so that prices can be stabilized and the balance between supply and demand maintained.

\section{The Importance of Vertical Housing Complexes in Absorbing Population Densities and Reducing Waste in The Use of Urban Land}

The approach of vertical construction means addressing vertical housing, which has become an urgent need to absorb population increases and provide decent housing. Countries have directed to building residential complexes through the public, private and even mixed sectors, making the possibility of investment in this sector possible, taking into account the social aspects that are directly related to improving the productive efficiency of the individual, including the provision of adequate housing for citizens with a relative focus on the vertical housing system (Al-Hiti, 1986, p. 9). In addition, a curriculum for vertical housing has been prepared in the centers of the governorates with the following objectives:

1) Increasing housing density when compared with horizontal housing.

2) Reducing costs for the implementation of public services (water, sewage, electricity, telephone and roads) in accordance with the economic and social potential of cities.

3) Providing many housing units suitable for the family in a specified period of time.

4) Provide an environment in which social interaction between the inhabitants.

5) Achieving social and economic stability for the family (Al-Janabi, 1985, p. 52).

The process of expansion of vertical housing includes several aspects, including:

- Economic aspects: The government and the private sector contribute to the establishment of housing units.

- Social aspects: By providing a suitable social environment for the livelihood of the population in a manner that guarantees privacy and independence.

Architectural and Structural aspects: To achieve the best designs for residential apartments in buildings that fit the nature of the social life of the population, as well as taking into account the environmental and climatic aspects of these designs, and give the building attractive forms reflecting the urban development, and give privacy within the general complex for each inhabitant in line with the concept of public housing (Al-Tikriti, 1982, p. 33).

\section{Uses of Urban Land in the City}

The concept of land use arises when addressing modern urban planning in three directions as a minimum:

- The functional spatial distribution of the city such as the distribution of land for housing, industry, trade, and administrative and recreational areas and services.

- There are those who see it in two parts, the purpose of which is to define urban areas. The first part is the employment activities of individuals, which are specific to the daily work activities. The second part is the general social, economic, health and other services, as 
well as the exploitation of the land in urban situation to serve the activities of the individuals associated with it.

- The third approach focuses on the relationship between the uses of activities within the limits of the previous two parts, i.e., the spatial distribution relationship with the activities of individuals and their services, as shown in Figure (1). Therefore, the urban land use can be defined as the use of natural space whether land alone or with natural or artificial additions such as forests, orchards, constructed buildings and others, to be legally released (Chad, 1987, p. 389).

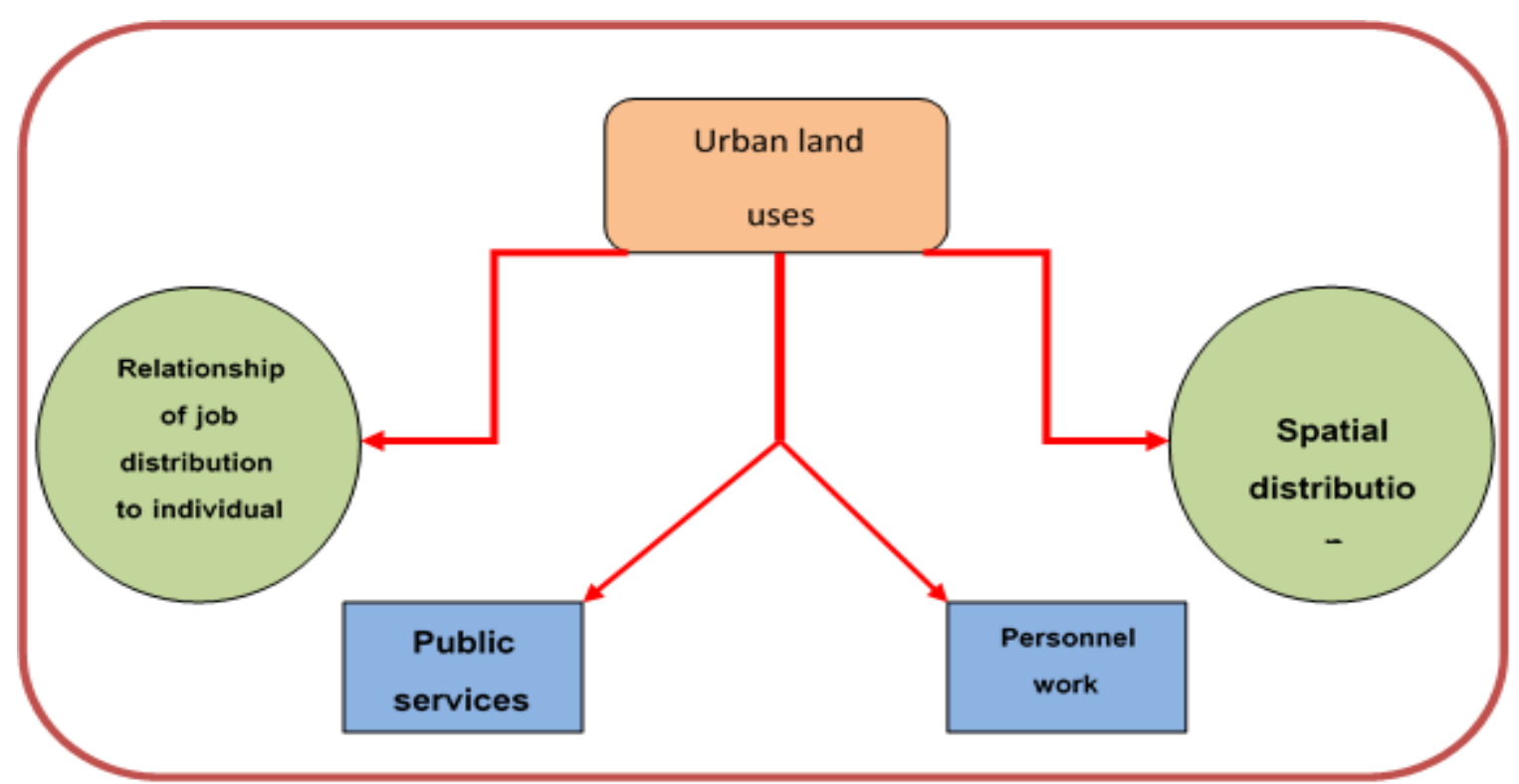

Figure 1: The spatial distribution relationship with the activities of individuals and their services Source: Researcher (Haidar, Farouk Abbas, "Town and Village Planning," Alexandria University, 1994, p. 151)

There is another definition that says, land use is the visual dimension of the area structure (the urban structure of the city), which consists of two parts:

- The first is determined by the various types of human activities that occupies spaces from the urban land, such as the activities practiced by man to obtain the requirements of daily life.

- The second is determined by the physical services and the various improvements of the urban land to be suitable for different types of human activities. The land uses are defined as the spatial distribution of the various functions of the city, which include residential, industrial, commercial, service, leisure and other functions (Chapin, 1976, p. 3).

The concept of urban land use is one of the broad and complex concepts, but it can be understood through the reciprocal and interactive relations between human and urban land. These uses represent the continuous change in the human relationship to the land and the creation of a balance between them, whereas the dependence of human on land is increasing accordingly due to the publication growth, because land is the spatial dimension on which the human rests and exploits its wealth and resources to meet his needs and to achieve the welfare he aims to reach. 
From all the above, land use is a concept that is applied to all places on the ground occupied by the urban structure such as buildings of the housing sector or roads and government building services and so on. In other words, it is a system of interconnected parts and units occupy a piece of urban land to meet the physical and moral human needs.

\section{Demand for the Urban Area and Spatial Space of the Residential Area}

The large cities in the world suffer from an abnormal population growth that does not coincide with other cities within the same country. This problem is one of the main dilemmas in developing countries, where demand for housing is increasing. This means increasing demand for urban land. The main reason for this increase is the migration from the countryside to the cities on the one hand, and to the improvement of the health level and low mortality rate with the high rate of births on the other hand. The most important reasons for migration to cities are:

- The relative rise in wage levels in cities.

- Job opportunities and increased demand for labour in cities as a reflection of urban development programs.

- Services are provided as educational opportunities in higher institutes and universities and provide health care such as hospitals and health clinics.

- The highly centralized Arab cities, which is characterized by the concentration of markets, goods, trade, entertainment, ministries and government departments.

The cultural and social aspects that characterize the people of the cities and the countryside (General Organization for Housing, 1982, p. 9).

The residential area represents the main spatial space of the urban system as it occupies the largest part of the city area and it is considered the main part of the urban area. The residential area is the place where people live. It consists of residential houses, gardens, and other uses such as local shops, schools, local and open spaces, and small service industries. The areas allocated for residential use differ from one city to another. Several studies have shown that residential use occupies an average area of 30-40\% of the city area (Haidar, 1994, p. 87). This percentage rises in most Arab cities as a result of the horizontal extension of this use, as it reached about (55.4\%) in Baghdad City (Hoshyar, 1976, p. 55). It is believed that residential vertical construction plays an important role in reducing the area of residential use and thus saving in urban land, which is important, scarce and limited. Due to the limited urban land in the city of Baghdad, instructions have been issued from the Municipality of Baghdad to allow the construction of a third floor for the current and future housing. Middle East cities, that characterized by their hot climate, need green spaces, recreational areas and swimming pools that can be provided by following the pattern of vertical construction, which alleviates the suffering of the population and make the city an environment that is comfortable for people. The residential use is an important and distinctive urban appearance of the city and an important factor in its composition. It is also an integral part of the urban fabric as well as the urban and social environment in which man grows and practices most of his activities. The other uses of land are:

- Commercial land use.

- Industrial Land Use.

- Recreational and green areas land use.

- Service and community land use.

- Residential land use. 
The land is subject to multiple human uses. From the economic point of view, the use of the land produces what so-called land use market. The land is seen in this market as a commodity traded and subject to supply and demand forces (Everson \& Fitzgerald, 1973, p. 114). There is a fierce struggle between the different types of functional uses to occupy the space in the city by renting or possession. This explains the Bid Rent model. This struggle over the place gets paid by the highest bidder to obtain the right to benefit, transfer, and use. Figure (2) shows the importance of urban land in the city.

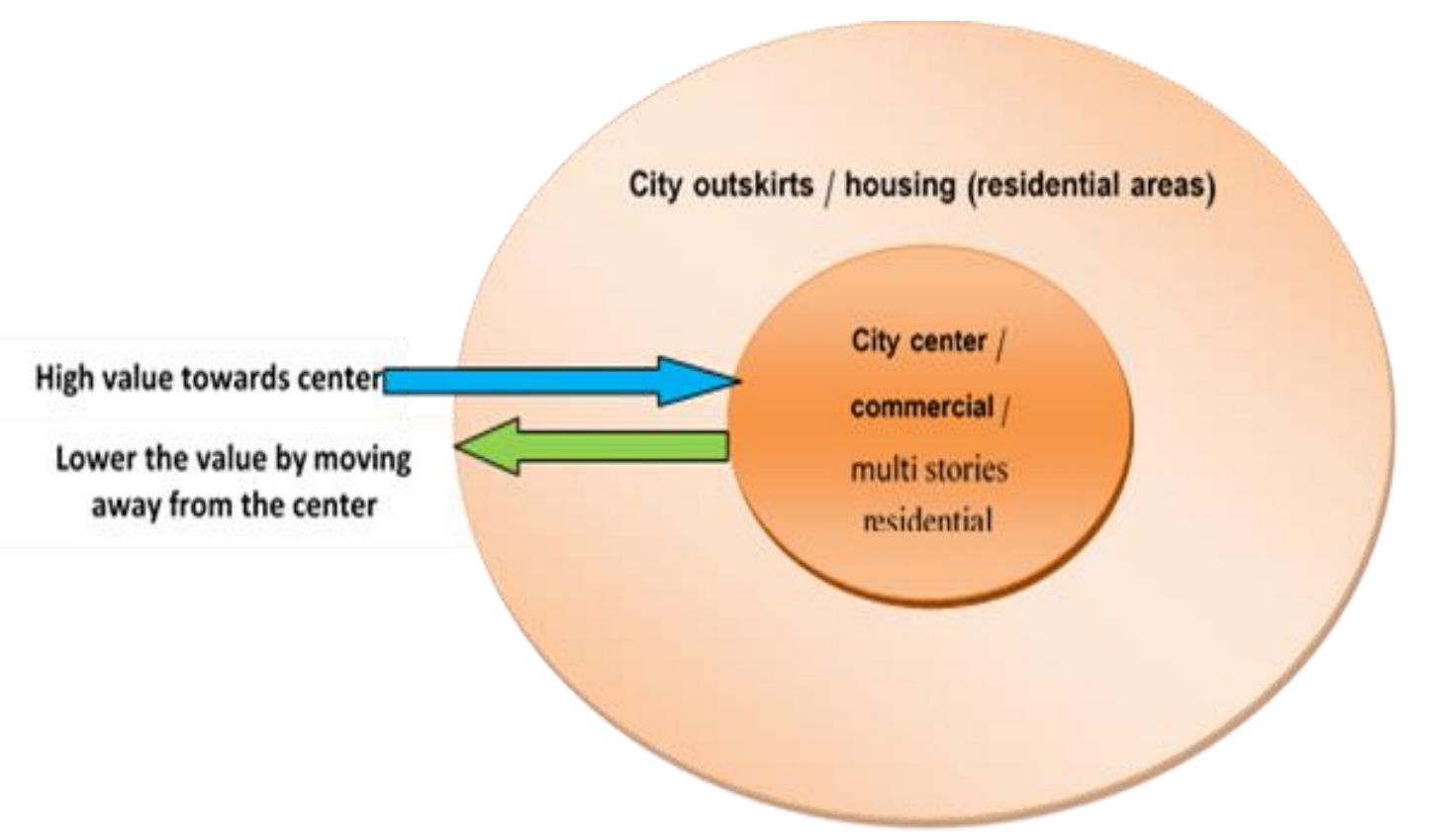

Figure 2: The importance of urban land in the city is placed in the city

Source: The researcher based on 40 (Garner, 1968, p3)

The architectural and historical value of the center is raised by the presence of these old neighborhoods, which represent the city's history, and are part of its architectural heritage (Keeble, 1976, p. 99). It is therefore important to go to the building in the center because of the scarcity of urban land.

\section{The Waste of Urban Land in Iraqi Cities and Comparing Them with the Global Cities}

The percentage of residential use, the area used for residential purposes, varies from one city to another. Hearle and Niedercorn (1973), accounted for about 30\% of the total area of the city and $39 \%$ of the total area in large American cities (Mullah, 1999, p. 36). Another study conducted by Bartholymew for 35 American cities, which found that the residential function occupies about $40 \%$ of the urban area. In another study found to be up to $43 \%$ of the area of the globe in British cities which exceeds ten thousand citizens, and in London city up to 42\% (Murphy, 1971, p. 369). In the Iraqi cities, the percentage of residential use rises to more than $60 \%$ of the area in large cities. In Baghdad, the percentage reached 62.7\% in 1977, while in Mosul it reached about 62\% in 1979 (Niedecorn \& Edward, 1973, p. 122). The reason for the increase in this percentage is due to the horizontal expansion of housing. The comparison between Tables (1) and (2) shows the extent of waste in urban land area in Iraqi cities because of horizontal expansion, which is the most common, 
so the Iraqi specialists of planning and design should stop at this situation and develop solutions and proposals for them that may lead to stopping wasting in the urban land. The housing function is often expanded at the expense of agricultural land. From here, the planners and who are concerned with the study of cities, began to pay attention to the issue of providing health housing within the city, where housing and reconstruction in many countries was considered part of the economic and social development policy, in addition to establishing planes for these policies and the development of construction materials and construction industries, which at the same time employ a large number of skilled and unskilled labour. The rate of residential use is undoubtedly high in Iraqi cities and especially in major cities because of the reliance on horizontal construction as a building method. Consequently, the continuation of this method will drain urban land, which is already characterized by scarcity. It is very crucial to adopt the vertical building approach alongside the horizontal approach to achieve sustainability in urban land.

Table 1: Percentage of land use in the urban area of Iraqi cities

\begin{tabular}{|l|l|l|l|l|l|l|l|}
\hline Type of Uses & $\begin{array}{c}\text { Hillah } \\
\mathbf{1 9 7 0}\end{array}$ & $\begin{array}{c}\text { Nejef } \\
\mathbf{1 9 7 3}\end{array}$ & $\begin{array}{c}\text { Khanikeen } \\
\mathbf{1 9 7 3}\end{array}$ & $\begin{array}{c}\text { Badrah } \\
\mathbf{1 9 8 3}\end{array}$ & $\begin{array}{c}\text { Baghdad } \\
\mathbf{2 0 0 0}\end{array}$ & $\begin{array}{c}\text { Baghdad } \\
\mathbf{1 9 7 9}\end{array}$ & $\begin{array}{c}\text { Baghdad } \\
\mathbf{1 9 7 2}\end{array}$ \\
\hline Housing & 33 & 36.7 & 74.7 & 76.4 & 53.6 & 62.6 & 60.2 \\
\hline $\begin{array}{l}\text { Commercial } \\
\text { and } \\
\text { administrative }\end{array}$ & ------ & 0.43 & 9.9 & 0.3 & 2.4 & 1.7 & 1.8 \\
\hline Industrial & 8.6 & 0.8 & ------ & ----- & 7.7 & 6.5 & 6.1 \\
\hline $\begin{array}{l}\text { Services and } \\
\text { public utilities }\end{array}$ & 11.5 & 3.4 & 1.8 & 7.6 & 1.0 & 0.5 & 4.4 \\
\hline Transportation & 32.2 & 16.4 & 12.6 & 13.7 & 15.9 & 15.7 & 14.2 \\
\hline $\begin{array}{l}\text { Open and } \\
\text { green areas }\end{array}$ & 14.2 & 35.6 & 1.0 & 1.9 & 14.9 & 2.9 & 3.8 \\
\hline Other uses & 0.5 & 5.09 & ----- & ------ & 4.5 & 9.1 & 9.5 \\
\hline Total & $100 \%$ & $100 \%$ & $100 \%$ & $100 \%$ & $100 \%$ & $100 \%$ & $100 \%$ \\
\hline
\end{tabular}

Source: - The researcher (Hitti, Hassan, 1986, p. 93)

Table 2: Percentage of Activities in the Urban Environment of the 10th of Ramadan City in

\begin{tabular}{|l|l|l|}
\hline \multicolumn{3}{|c|}{ Egypt } \\
\hline 1 & Land Use & Percentage \% \\
\hline 2 & Industrial & 28.4 \\
\hline 3 & Roads and Spaces & 26 \\
\hline 4 & Parks and Gardens & 14.4 \\
\hline 5 & Commercial & 1.2 \\
\hline 6 & Tourist & 2 \\
\hline 7 & Public Services & 7 \\
\hline & Total & 100 \\
\hline
\end{tabular}

Source: The work of the researcher based on the site; http://www.tortp.gov.eg/arabic/site.htm

In comparison with a city based on vertical residential construction (the residential housing complexes), the tenth of Ramadan city in the Arab Republic of Egypt, Table (1) shows the difference in the percentage of residential use of vertical housing and horizontal residential 
housing, which is a great waste of urban land. As an example of comparison in Baghdad city, the proportion of residential use is about (60\%) and in the 10th of Ramadan city is about (28\%). This difference is more than double, so there must be review by stakeholders to reduce the ongoing waste of urban land in recent times, which is characterized by its scarcity. Figure (3) illustrates a plan for the tenth of Ramadan city in the Arab Republic of Egypt.

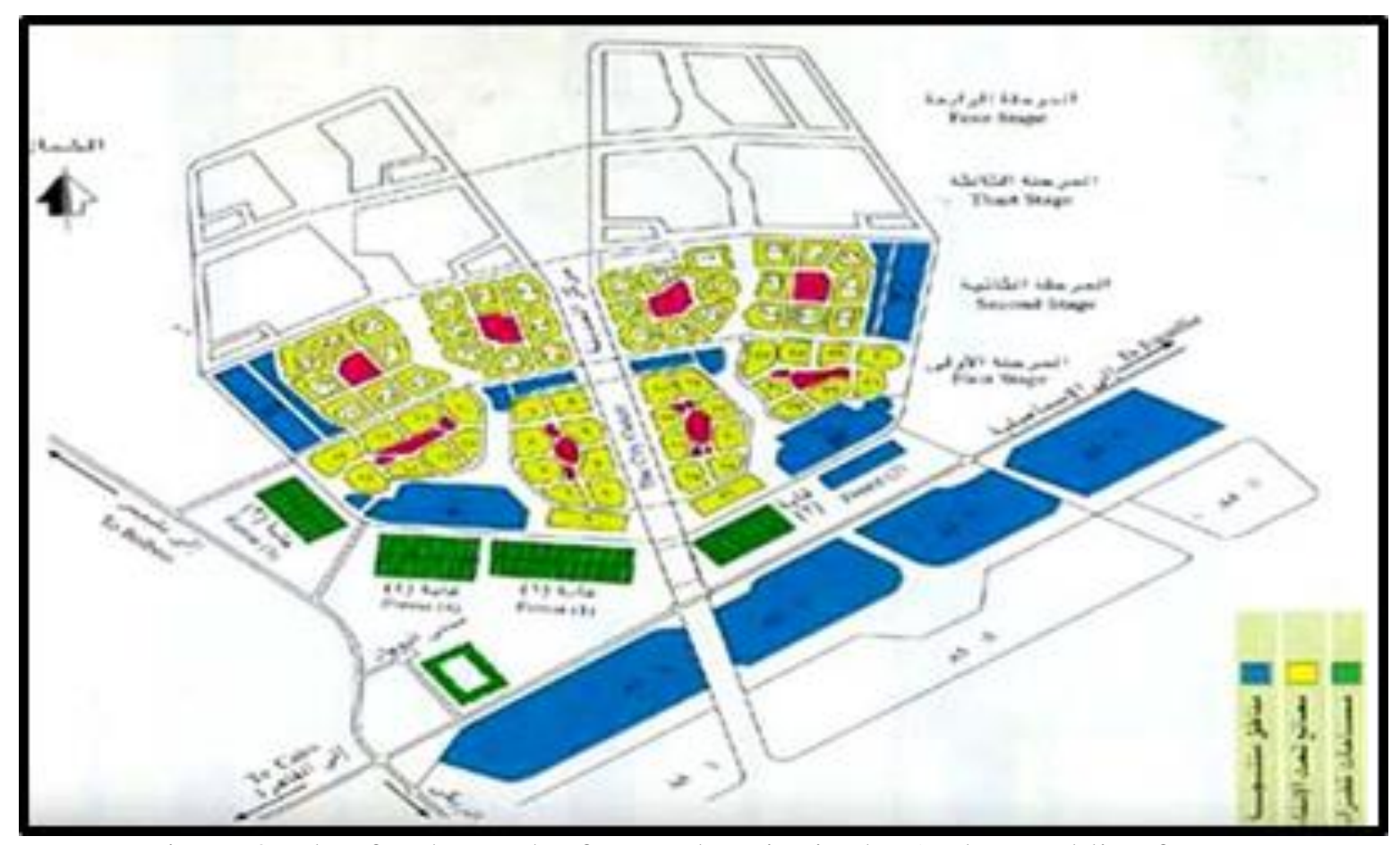

Figure 3: Plan for the tenth of Ramadan city in the Arab Republic of Egypt

The comparison between the residential use ratios in Iraqi cities and the 10th of Ramadan city as an example of an Arab city depends on vertical housing construction in the form of housing complexes showing the extent of waste in the area of urban land in Iraqi cities because of the horizontal expansion. So, it should be stopped at this situation and try to develop solutions and proposals for them by specialists in planning and design, which could lead to limit the waste in urban land. The presentation of this city and the proportions of land uses in it was because the style of the building is a vertical housing construction for comparison only.

\section{The Extension and Horizontal Expansion of Iraqi Cities and Their Relationship with Scarcity of Urban Land}

The situation of the horizontal expansion of Iraqi cities may be one feature. This is clearly evident in Baghdad city. This expansion of Baghdad in 1956, which increased and peaked at the beginning of the 1960s, was a chaotic expansion (Oktay, 1980, p. 5). This expansion continued until the area of Baghdad reached $\left(900 \mathrm{~km}^{2}\right)$. Horizontal expansion is also a negative reflection of the excesses in the distribution of residential plots with wide areas ranging between $\left(200-600 \mathrm{~m}^{2}\right)$, and sometimes in particular reach to $\left(1000 \mathrm{~m}^{2}\right)$ or more. This has led to a lack of use of spaces for urban land, where the density of housing has decreased and the expansion at the expense of many orchards and fertile agricultural land. The bad effects of this expansion is the failure of the 
municipal departments to deliver services and public utilities to the population, and then this horizontal extension creates problems such as traffic congestion, it also causes boredom in the human psyche and the repetition of stone patterns that fall off sight, as well as the lack of significant points as a monumental architecture or a distinctive building in this similar structural pattern in Iraqi cities. The population growth rate recorded from 1960 to 1978 is 3.1\% per year. This indicates an increase in population growth as a result of improved health and social conditions (Orville \& Grimes, 1979, p. 42). After knowing the negative impact of horizontal expansion, a stop has been done to establish a solution to this situation. The alternative direction should be the expansion of the vertical residential and the creation of the appropriate areas for the construction of functionally integrated vertically residential complexes, which should be integrated services, spaces and recreational services at appropriate economic and social levels and benefit from the experiences of countries such as Arab, regional and foreign in this field.

\section{Vertical Housing Complexes and Their Importance in Preserving Urban Land}

Residential housing complexes have become necessary for the preservation of urban land and the reduction of waste. The importance of these complexes comes from the role of these housing complexes in solving the housing crises and problems. The provision of housing units in the residential housing complexes has become a priority for the interest of investors and the public sector represented by the Ministry of Housing and Reconstruction in Iraq because, by following this pattern, it is possible to achieve housing projects containing thousands of housing units in a timely manner and very good quality, as well as creating a comfortable and integrated social environment services that attract families to live in these complexes. Due this importance, the Ministry of Housing and Construction, as they represent the public sector is implementing many of these complexes on the level of Iraq, has realized the importance to adopt the method of building residential complexes to distinguish them in the preservation of urban land with greater absorption of residents. The majority of countries in the world began to build vertical housing complexes on a large scale to take advantages of this style for its speed in meeting the housing need, and for the lack of need for large areas of land. The most important in these residential complexes is the application of the standards of planning and engineering reaching to the functional integration in achieving a social environment characterized by social interaction and social relations. In table (3), a clear representation of the importance of housing complexes through the basic information about this residential complex. Figure (4) shows one of the projects implemented by the Ministry of Housing and Reconstruction.

Table 3: The basic information about the project of Sauilm

\begin{tabular}{|c|c|}
\hline Project name Kess and Swilm 1 & \multirow{9}{*}{$\begin{array}{l}\text { General } \\
\text { information }\end{array}$} \\
\hline Location / Babil Governorate / Road to Najaf Governorate & \\
\hline Area of the site / 14.5 ha & \\
\hline Population: 3024 inhabitants & \\
\hline Number of housing units / 507 housing units & \\
\hline Number of residential buildings / 61 residential buildings & \\
\hline Building area for residential buildings 5,189 hectares & \\
\hline Percentage of residential use / $35 \%$ & \\
\hline Multi-family housing style & \\
\hline
\end{tabular}

Source / Researcher depending on project data 


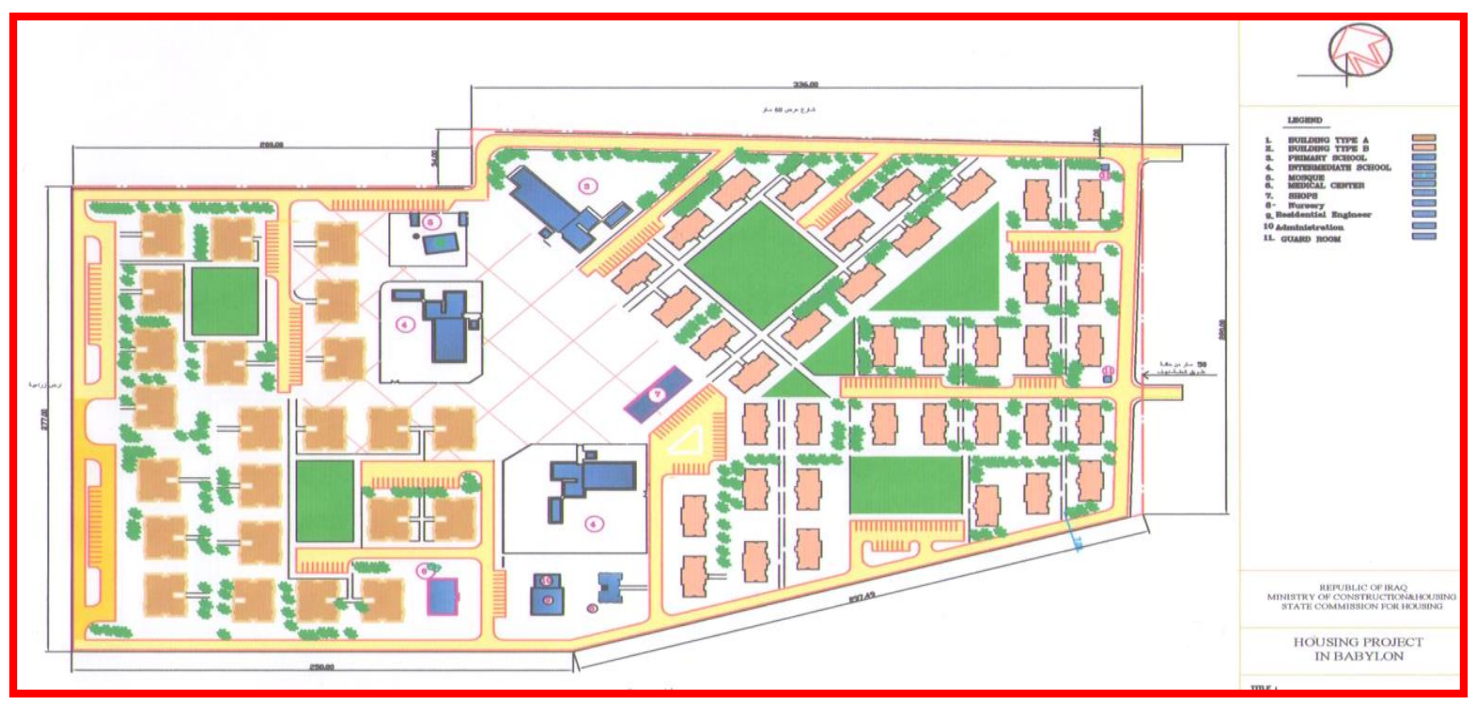

Figure 4: Vertical multi stories residential building in Kess and Sweilem 1

Source: Ministry of Housing and Construction - General Establishment for Housing

\section{Application Side}

In order to enhance the theoretical aspect of the research, the researcher should use the field study. The residential complex was chosen in Dour District because it is considered an ideal model for conducting the applied side of the research. The following satellite image is shown in Figure (5) represents the horizontal special plan of the complex. This complex contains integrated social services and has been carried out by French companies in the eighties of the last century according to the best specifications.

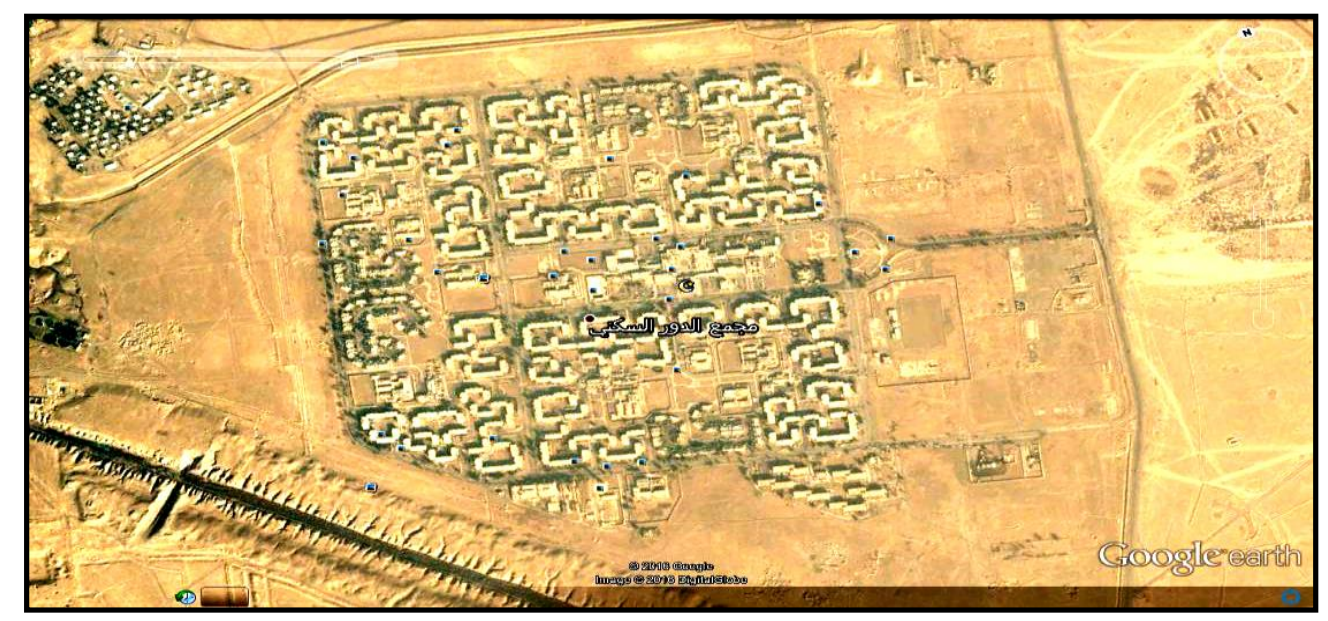

Figure 5: Satellite image for the space of Dour multi stories residential building Source: Google Earth

The residential buildings in Al-Dour residential complex were designed using a vertical housing construction style (vertical housing), consists of three-storey and four-storey buildings. This residential complex is located to the south Al-Dour district near to Samarra district within the governorate of Salah Al-Din province. Figure (6) shows the location of the residential complex with respect to the map of Iraq. Figure (7) shows a number of residential units in the complex. 


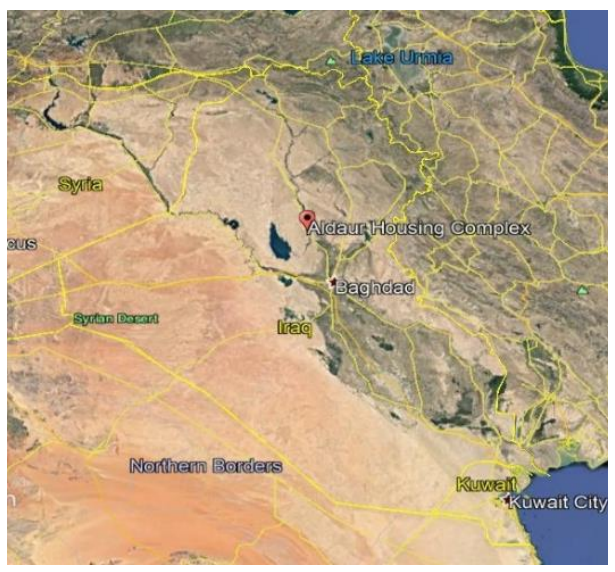

Figure 6: location of the residential complex with respect to the map of Iraq Source: Google Earth
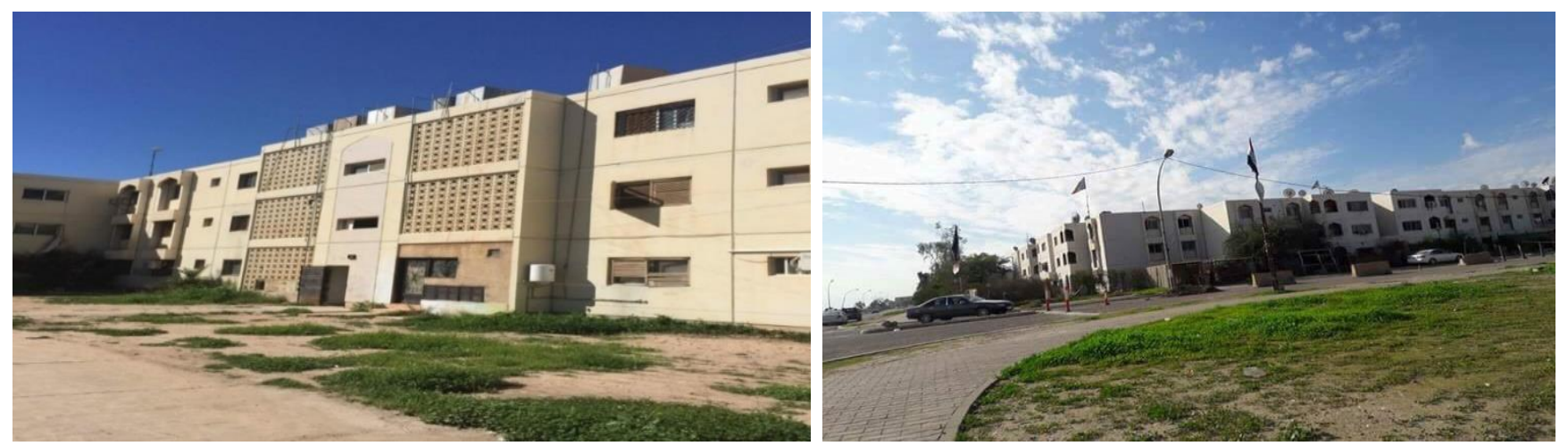

Figure 7: A number of residential units in the complex

Source / researcher direct photography from the study area

\section{Results and Discussions}

Area, population and number of residential units in Al-Dor residential complex

Table (4) below shows the number of inhabitants, the number of housing units and the area of the complex.

Table 4: Area, Population, number of residential Units in the Residential Complex

\begin{tabular}{|l|l|}
\hline Area of the residential multi-stories building & 66 hectares \\
\hline Number of housing units & 2800 housing units \\
\hline Population in the multi-stories & 18560 people \\
\hline Total residential density & 50 housing units/ha \\
\hline Population density & 281 people / ha \\
\hline
\end{tabular}

Source: Preparation of the researcher based on data from the General Organization for Housing, Department of Designs and Studies, unpublished study, Baghdad, 1982 p. 9.

Table (5) shows that this residential complex is considered one of the functionally integrated complexes, in line with the need of the residential complex, where it consists of educational services starting from kindergarten to secondary schools, as well as containing the different 
cultural and youth centers and police centers to maintain security as well as firefighters, medical center and communications. It also contains the markets in the six residential buildings that comprise the complex as well as other central markets. The complex also contains a sports court equipped and swimming pool with Olympic standards and contains stations that provide service to the residents of the complex.

Table 5: The contents of the housing multi stories complex of social building services

\begin{tabular}{|l|l|l|}
\hline No. & Social Service Buildings & Quantity \\
\hline 1 & Elementary school & \\
\hline 2 & Middle school & 2 \\
\hline 3 & Highschool & 2 \\
\hline 4 & Kindergarten & 1 \\
\hline 5 & Incubation & 1 \\
\hline 6 & medical Center & 1 \\
\hline 7 & Fire Fighting Center & 1 \\
\hline 8 & police station & 1 \\
\hline 9 & young's Center & 1 \\
\hline 10 & call center & 1 \\
\hline 11 & Markets in residential stores & 6 \\
\hline 12 & Central markets in the multi stories residential building & 5 \\
\hline 13 & Mosque & 1 \\
\hline 14 & Stadium & 1 \\
\hline 15 & Cultural center & 1 \\
\hline 16 & Olympic Swimming Pool & 1 \\
\hline 17 & Fuel filling station & 1 \\
\hline 18 & Oil and gas processing plant & 1 \\
\hline 19 & Water purification plant & 1 \\
\hline 20 & Sewage station & 1 \\
\hline 21 & Power plant & 1 \\
\hline 22 & Hotels for singles accommodation & 6 \\
\hline
\end{tabular}

Source / researcher based on the field study and the management of the multi-stories building

\section{Uses of Land in the Multi-Stories Residential Building}

The different uses of residential, commercial, social, open and green spaces were distributed, and Table (6) shows this.

From Table (6) and Figure (8), it is concluded that the residential use is (26.3\%) of the total land area allocated to this residential complex of 66 hectares. This percentage is consistent with the proportions in the modern urban cities which are concerned with the conservation of urban land. The percentage of residential use in cities that depend on wide horizontal construction may reach $60 \%$ or more. Here, the relationship between urban land and vertical housing complexes and the role of these complexes in preserving urban areas is highlighted without wasting. The largest proportion was for green areas, which are of great importance cities as they have a positive impact on the health and psychological side of citizens. 


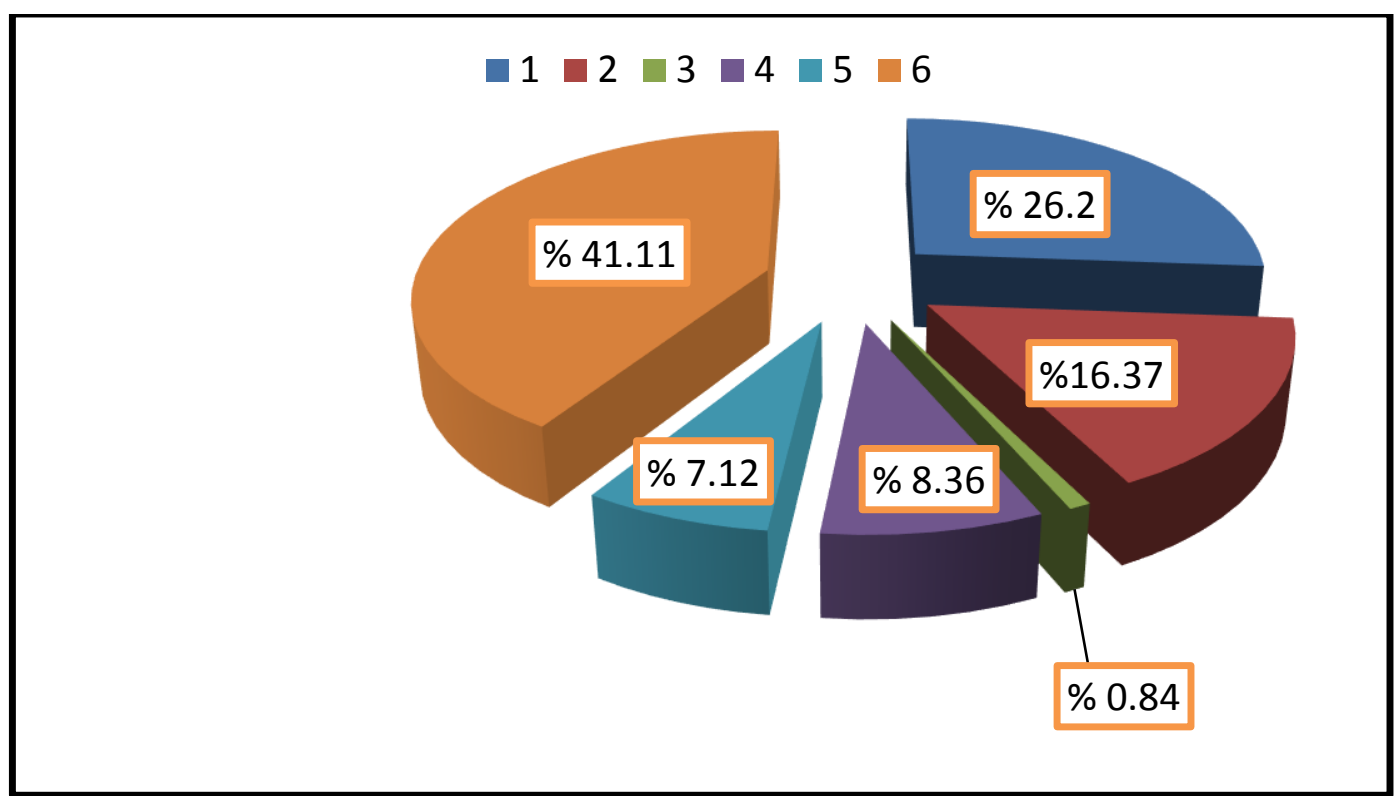

Figure 8: Land use distribution ratios for the study area

1-Residential buildings 2 - Schools buildings $3=$ Local markets $4=$ Roads $5=$ Car parks $6=$ Green areas

Table 6: Distribution of land use of the multi-stories residential building

\begin{tabular}{|l|l|l|l|}
\hline No. & Type of use & Area (ha) & Percentage \% \\
\hline 1 & Residential buildings & 17.292 & 26.2 \\
\hline 2 & School buildings & 10.8 & 16.37 \\
\hline 3 & Local markets & 0.5544 & 0.84 \\
\hline 4 & Roads & 5.517 & 8.36 \\
\hline 5 & Parking & 4.7 & 7.12 \\
\hline 6 & Green areas and walks & 27.132 & 41.11 \\
\hline 7 & The total area & 66 & $100 \%$ \\
\hline
\end{tabular}

Source: Public Institution for Housing, Department of Design and Studies, unpublished study

\section{Conclusions and Recommendations}

The main conclusions of this research are as follows.

- Residential use accounts for the largest proportion of urban land use in the horizontal building type (i.e. single houses), in cities with horizontal expansion, as is the case of Iraqi cities, although urban land is always characterized by scarcity.

- The construction of vertical housing complexes achieves a lower proportion of residential use of urban land may be up to half compared to horizontal residential construction, depending on the number of floors consisting of residential buildings and the planning and design of those buildings and residential complexes.

- The horizontal expansion of cities increases the percentage of residential use of land, which is at the expense of proportions of other uses.

- Most countries in the world have followed the method of building multi-family residential complexes on a large scale due to the speed meeting of the housing needs, especially if characterized by functional integration. 
- The horizontal expansion is a result of the excess in the distribution of residential plots with large areas, and this led to a lack of use of areas of urban land, where the density of housing is low and the expansion is at the expense of many of the fertile agricultural land surrounding cities, which is supposed to be a backer for them.

- Housing in vertical residential complexes is more able to accommodate population increases with increasing residential density and urban urbanization with proper treatment for the growing housing need in Iraq.

- The requirements of vertical housing are represented by services, educational, health, commercial and entertainment requirements. Therefore, when implementing the vertical residential complexes must be implemented with all the requirements to make housing in these complexes comfortable and achieve its objectives, which are complexes with functional integration.

- The author concludes that the residential use is (26.3\%) of the total area of land allocated to the residential complex which is about 66 hectares. This ratio is consistent with the proportions in the cities of the modern world, which concern the conservation of urban lands without wasting.

- The proportion of land allocated to green areas and walks has increased to reach $(41.11 \%)$. This is a positive aspect because the increase in this percentage has positive health implications for the residents of that complex.

\section{Recommendations}

The main recommendations of the research are as follows:

- The need to give more attention on the construction industries of various types to reach self-sufficiency because the output of this industry is the raw material for the production of housing units and to reduce the import of these materials and thus reduce costs of residential units, especially in vertical residential complexes because it is considered as a large residential production.

- Conducting design and planning competitions for residential complexes at the state level involving the relevant universities and Consultation offices from inside and outside Iraq in order to reach different models of these complexes that fit the local environmental and social reality and focus on functional integration.

- Choosing suitable places for residential complexes in Baghdad and other governorate centres, with an aesthetic nature, taking into consideration that they are fully serviced.

- Rehabilitation of companies affiliated to the Ministry of Construction and Housing, such as Al-Faw company and others, directing them towards building vertical residential complexes and creating competition among them in this direction, and giving greater role to the private sector in order to contribute to the construction of housing units through creating cooperation between public and private sectors.

- Rehabilitation of prefabricated construction laboratories and building more of them to contribute to the production of residential units because of the speed of this method in implementation and reduction in costs, especially with regard to the external finishes.

- The trend towards the adoption of multi-storey residential buildings with a height of (3-5) floors, which are preferred by the Iraqi community in order to contribute effectively in facing the accumulated housing needs. 
- Pay attention to the role of the private sector to participate in the investment in the housing sector, especially after the issuance of the law of an investment in Iraq, facilitate the procedures in this area, and the establishment of cooperation systems between the public and private sectors.

- The examination of the experience of some countries in the housing sector and benefit from them to develop the reality of the housing sector.

- Giving priority to residential complexes projects in banking facilities, tax exemptions and facilitating import transactions for the purpose of encouraging investors to move to this field.

- Vertical housing complex should be implemented with all the requirements to make housing in these complexes housing qualified and comfortable, achieving its objectives and attractive to the population.

- The allocation and preparation of residential land, in general, should be managed and directed by the central government and local governments according to the master plans of the cities. It is supposed to allocate places for vertical housing complexes and, if needed, update these plans.

\section{References}

[1] Ahmed, Amira Jalil (2004). "PLANNING AND DESIGN EFFECTS OF LOCAL LOW-COST HOUSING SITES" Master Thesis submitted to the Department of Architecture, University of Technology, Baghdad.

[2] Al-Haidari, Sana Shata (1981). "HOUSING RENEWAL" Master Thesis submitted to the Faculty of Engineering, University of Baghdad.

[3] Al-Hayti, Salih Falih Hassan (1976). "DEVELOPMENT OF THE RESIDENTIAL FUNCTION OF THE GREATER CITY OF BAGHDAD FOR THE PERIOD (1950-1970)” Dar es Salaam Press, Baghdad.

[4] Al-Hiti, Sabri Fares and Saleh Falih Hassan (1986). "GEOGRAPHY OF CITIES" University of Mosul Press.

[5] Al-Janabi, Salah Hamid (1985). "THE USES OF THE LAND BETWEEN THEORY AND PRACTICE" An Empirical Study on the Greater Mosul, University of Mosul Press.

[6] Al-Tikriti, Iyad Mohammed Saleh (1982). "PLANNING OF VERTICAL HOUSING IN THE CITY OF BAGHDAD IN THE LIGHT OF SOCIAL REQUIREMENTS" Master Thesis submitted to the Urban and Regional Planning Center, University of Baghdad.

[7] Chad Wick, George (1978). "A SYSTEM VIEW OF PLANNING, TOWARDS THE THEORY OF THE URBAN AND REGIONAL PLANNING PROCESS” Pergamon Press, 2nd Edition, England.

[8] Chapin, F.S (1976). "URBAN LAND USE PLANNING” 2nd Edition, university of Illinois press, USA.

[9] Everson, J. A. \& Fitzgerald, P. F. (1973). "INSIDE THE CITY" Langham second Impression Hongkong.

[10] General Organization for Housing, Department of Design and Studies (1982). "A STUDY OF THE CONDITIONS OF RESIDENTIAL BUILDINGS IN ZAYOUNA” Rusafa, unpublished study, Baghdad.

[11] Haidar, Farouk Abbas (1994). "PLANNING CITIES AND VILLAGES" University of Alexandria.

[12] Hoshyar, Super (1976). "VERTICAL HOUSING AND REAL ESTATE REGISTRATION LAW" Journal of Justice, No. 1. 
[13] Keeble, Lewis (1976). "PRINCIPLES AND PRACTICE OF TOWN AND COUNTRY PLANNING" 4th Edition, The Estimates Gazette Ltd, London.

[14] Mullah Hweish, Louayatah (1999). "THE IMPACT OF THE NEW HOUSING STYLE ON SOCIAL BEHAVIOR" Ph.D., Introduction to the Center for Urban and Regional Planning for Postgraduate Studies, University of Baghdad.

[15] Murphy, Raymond E. (1971). “THE AMERICAN CITY-AN URBAN GEOGRAPHY” Mc. Graw Hill-Inc. New York.

[16] Niedecorn, John .H, \& Edward, F.R. Hearle (1973). "RECENT LAND USE TRENDS IN FORTYEIGHT LARGE AMERICAN CITIES.

[17] Oktay, Ural (1980). "CONSTRUCTION OF LOWER COST HOUSING" Wiley series of construction guides, 1 st ed, John Wiley\& Sons press.

[18] Orville \& Grimes, Jr. (1979). "HOUSING OF LOW-INCOME URBAN FAMILIES" Economic and policy in the development world.

\footnotetext{
*Corresponding author.

E-mail address: nabiltaha2001@ gmail.com
} 